\title{
The Function and Perception of Urban Ecosystem Services in the Society
}

\author{
Funkcja i postrzeganie usług pełnionych przez \\ ekosystemy miejskie w społeczeństwie
}

\author{
Fredrik Edlund
}

\author{
Enviroment and Energysystems, Karlstads University, Karlstad, Sweden \\ E-mail: fredrik.edlund@gmail.com
}

\begin{abstract}
The urban development that is now taking place globally has led to the most extensive permanent land use that has caused ecosystems to be destroyed and the depletion of natural resources. Today, about $50 \%$ of the world's population lives in urbanized cities and by 2030 it is estimated to be about $70 \%$. The fact that we gather in larger numbers in cities means that we transport large volumes of resources to these areas, which gives rise to waste and emissions, which places a burden on the neighboring environment to the it's limits. This leads to problems for both human health and society's economy, which is because the ecosystems that help us, collapse. To counter this, a better urban planning is required which includes the environment in society as ecosystem services. The problem with ecosystem services is that they do not have a commercial value, which makes it difficult to implement since they do not indicate any economic gain. Therefore, it is necessary to increase knowledge about how they contribute so that they can be correlated to how they contribute to society from three aspects: economic, social, environmental.
\end{abstract}

Key words: Ecosystem services, Green Infrastructure, Urban planning, Urbanization

\section{Streszczenie}

Rozprzestrzenianie się miast, który odbywa się obecnie na całym świecie, doprowadziło do największego stałego zajęcia gruntów, oznaczającego zniszczenie ekosystemów i wyczerpywania się zasobów naturalnych. Obecnie około $50 \%$ światowej populacji mieszka w miastach i szacuje się, że do 2030 r. będzie to około $70 \%$. To, że gromadzimy się coraz liczniej w miastach, oznacza, że musimy transportować duże ilości zasobów do tych obszarów, co powoduje powstawanie odpadów i emisji zanieczyszczeń, co obciąża sąsiadujące z miastami środowisko do jego granic. Prowadzi to do powstawania problemów odnoszących się zarówno do ludzkiego zdrowia, jak i gospodarki społecznej, ponieważ ekosystemy, które mają nam pomagać, ulegają zniszczeniu. Aby temu przeciwdziałać, konieczne jest lepsze planowanie miast, które uwzględniałoby pełnione przez środowisko w społeczeństwie usługi ekosystemowe. Problemem jest to, że takie usługi nie mają one wartości handlowej, co utrudnia ich uznanie, ponieważ nie wskazują na żadne korzyści ekonomiczne. Dlatego konieczne jest pogłębienie wiedzy na temat ich znaczenia, aby można było je skorelować z tym, jak służą społeczeństwu w trzech wymiarach: ekonomicznym, społecznym i środowiskowym.

Słowa kluczowe: usługi ekosystemowe, zielona infrastruktura, planowanie miast, urbanizacja

\section{Introduction}

Over the past centuries, man has gone from living in smaller villages / cities to big cities, this phenomenon is called urbanization. Globally, urbanization has led to the most extensive permanent use of land surfaces and the change of its nearby green area (Andersson-Sköld et al., 2018).

Today, about 50 percent of the world's population lives in urban areas and the development suggests 
that by 2030 it will increase to about 70 percent $(\mathrm{Ni}-$ kodinoska et al., 2018).

This development has led to ecosystems and natural resources being depleted and creating an imbalance in the environment, as large volumes of resources are transported and accumulated in one area and give rise to large amounts of waste and pollution. This causes the area to be heavily burdened by pollution that causes economic resources and the health of the population to be affected.

The UN's Agenda 2030 has 17 goals to work with for a more sustainable development for our planet. Objective 15, with the aim of: ... protecting, restoring and promoting the sustainable use of land-based ecosystems, sustainable use of forests, combating desertification, stopping and reversing land degradation and halting the loss of biodiversity (Regeringskansliet, 2015).

As the population grows globally and trends indicate that we are increasingly moving towards urbanization, pressures on the environment will increase, and must be met by systems that can counteract these pressures (Vallecillo et al., 2018; Wilkerson et al., 2018).

Ecosystem services is a concept that aims at the products and services that nature's ecosystem provides to man and that contributes to our well-being and quality of life. Like for example: pollination, natural water regulation and nature experiences (Naturvårdsverket, 2019).

These services can be integrated into our societies in order to achieve an increased balance in the environment, but also an increased well-being for the population. The integration can form the basis for supporting biodiversity and ecosystem services, improving air quality, regulating microclimate, beautification of urban landscape, preventing and mitigating traffic and providing leisure entertainment for the population (Naturvårdsverket, 2015; Wang Y. et al., 2018).

In the earlier stages of the industrialization, the Western world has not taken much account of the environment since there was confidence in the dilution of the environment. This means that environmental aspects in decision-making processes rarely received priority, but economic and social aspects were those that were driving decision-making. Over time, we have increased our population and our production and consumption habits, which means that many ecosystems are now being completely eliminated or are on the verge of collapse. This contributes to that our financial resources and human health is suffering from environmental problems (Demuzere et al., 2014; Elmqvist et al., 2015).

For developing countries, eg China and India, which are now expanding their urban environments to accommodate a larger population and industries, have shown that the health of the population has deteriorated. This development is similar to the one that occurred during the Western world industrialization but is much more extensive as these countries not only produce for themselves but the whole world (Xiao et al., 2017; Zinia \& McShane, 2018).

In a society that is moving towards urbanization where the majority of the population is gathered on a smaller area, the region is subjected to a considerable amount of different types of waste that arise as a result of our lifestyle. The waste produced erodes the surrounding environment which affects our economy and can directly or indirectly harm people's health psychologically and physically. Therefore, it is important for urban planning to integrate the environmental aspect and the ecosystem services that help the people and the environment in order to live a safe and healthy life and not at the expense of the environment (Wilkerson et al., 2018).

The aim of the literature study is to look at how urban ecosystem services can be beneficial in a society both socially and economically and methods for valuing these services.

\section{Method}

Karlstad University Library's search engine OneSearch was used to find relevant literature for this study.

First, an overall search for ecosystem services was made to increase understanding of the subject. The increased understanding resulted in several search phrases that could be used to make the search more focused. The phrases used in the searches are in English to get literature from as large a range as possible. For all searches, articles were chosen from 2017 onwards in order to get as up-to-date information as possible. Only peer-reviewed academic journals were included, Newspapers, e-books, trade magazines and reviews were excluded from the study.

The Advanced Search function was included which allows three phrases in a search. There, the first two were always Urban ecosystem services and Urban green infrastructure, the third was varied to angle the search to relevant areas. From the searches the first 100 articles were reviewed by reading the title to see if it was relevant and then the summary to add the literature. Search the phrases and the number of hits are shown in the table 1.

Table 1. Number of hits each search gave. The top row was used for the overall search within the area.

\begin{tabular}{|l|c|c|c|}
\hline Phrases & Hits & $\begin{array}{c}\text { Se- } \\
\text { lected }\end{array}$ & $\begin{array}{c}\text { Recurring } \\
\text { selected } \\
\text { hits }\end{array}$ \\
\hline $\begin{array}{l}\text { Urban ecosystem services } \\
\text { Urban green infrastructure }\end{array}$ & 7961 & 17 & - \\
\hline Estimating model & 1593 & 5 & 5 \\
\hline Willingness to pay & 757 & 4 & 7 \\
\hline Payment for ecosystem services & 1122 & 5 & 3 \\
\hline Replacement method & 950 & 4 & 5 \\
\hline Socio-economics & 2658 & 8 & 7 \\
\hline Spatial planning & 4259 & 4 & 6 \\
\hline Economic benefits & 5294 & 5 & 4 \\
\hline
\end{tabular}




\section{Urban Socioecological System}

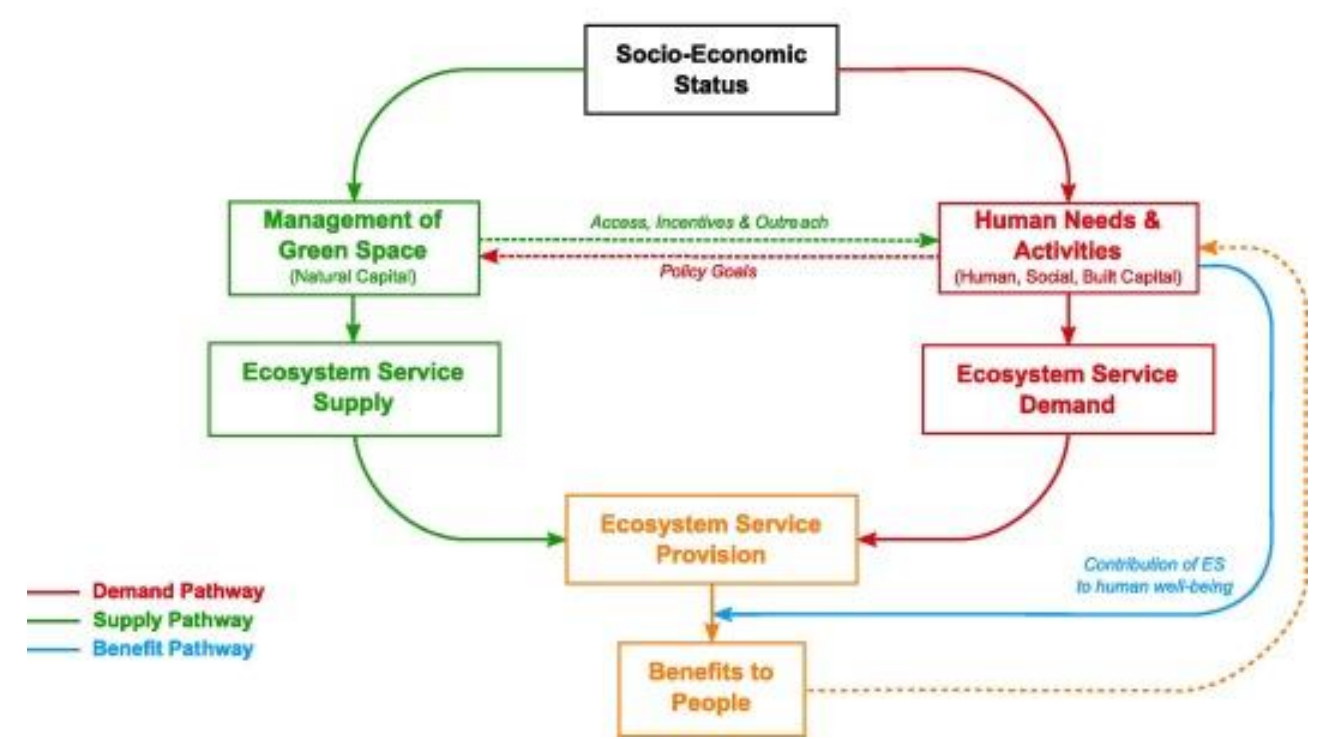

Figure 1. How socio-economic status affects the flow of ecosystem services in an urban socio-ecological system. The different coloured components refer to the three main routes through which socio-economics can affect the supply of ecosystem services.

\section{Literature review: Ecosystem Services}

Urban ecosystem services

Urban ecosystem services are aimed at a variety of environments that are implemented in a society and can be categorized as green or blue. Green refers to: parks, city forests, cemeteries, vacancies, gardens and landfills and the blue: streams, lakes, ponds, artificial ramparts and storm water holding ponds. This means that there is a high demand for ecosystem services in urban environments where there are a large number of users who can take advantage of it (Elmqvist et al., 2015; Roebeling et al., 2017; Feltynowski et al., 2018).

The challenges with urban ecosystem services are that they address land surface in areas that are considered to have strong commercial value and can therefore be a problem in decision-making about how the land should be used for society. These areas can therefore easily fall for opportunism, which means that the area is instead becomes a contributing source for emissions and pollution of the environment. Another challenge is that they have to be maintained in the aspects of cleaning, security or any other form of administration, otherwise they lose their function and value. The financing of the maintenance usually comes from state resources such as taxes, management funds or ticket revenues (Jiang, 2017; Chiara, 2018; Wang Y. et al., 2018).

Studies also show that knowledge of urban ecosystem services for both state, organizations and individuals raises the value and function of the service. For state and organizations it's about how and where to implement it in order to achieve the best function and therefore get a financial understanding of the service more easily. For individuals it is to know how it affects the human body to stay in green areas and in that way appreciate the value of it. The knowledge also leads to such implementations being better cared for and appreciated by the whole society (Elmqvist et al., 2015; Wang Y. et al., 2018; Wilkerson et al., 2018).

\section{Green infrastructure}

Green infrastructure aims to including in urban planning varying types of ecosystem services to fulfil different functions in society. Using green infrastructure in urban planning includes protecting, preserving, restoring and recreating habitats, ecosystem functions, and natural processes. This is to manage the natural resources that exist locally and regionally. This helps to secure a functional and sustainable society (Derkzen et al., 2017; Wang J. \& Banzhaf, 2018; Wang Y.-C. et al., 2018).

Implementing green infrastructure has been applied to many projects, but some have not fulfilled any major function or social benefit more than visually. This is often the case if shortcuts are made as financial reasons for the cost of plant and maintenance. Using green infrastructure only for visual functions in urban planning is commonplace but undermines its purpose of fulfilling many functions that are of benefit to society (Demuzere et al., 2014; Huang et al., 2018; Mabon \& Shih, 2018; Marino \& Lapintie, 2018).

\section{Social effects}

People have many needs that they feel that a society must be able to satisfy. Everything from basic needs like clean air, fresh water, financial security and safety from disasters. As economic security increases, trends show that the need for self-actualiza- 
tion becomes increasingly important for the individual. This is important for how different ecosystem services can be prioritized in a society and can be used to promote well-being and fulfil the needs that they have (Chen et al., 2018; Wilkerson et al., 2018). We can adapt ecosystem services to our needs in the communities, but they usually give rise to several effects that are beneficial to our well-being. Studies show that there is a connection between elements of nature, such as parks, reduce stress and strengthen mental health (Hegetschweiler et al., 2017; Amano et al., 2018; Chiabai et al., 2018).

But there are also studies that show that parks can be a stress factor. In some areas of Asia and Africa, there are debates about the valuation of city parks as they are associated with crime such as violence, sexual abuse and theft. This is because the vegetation in the parks makes it difficult to have a functioning safety for the visitors (Shackleton et al., 2017; Kim \& Jin, 2018; Mexia et al., 2018; Wilkerson et al., 2018).

As mentioned earlier, the design of ecosystem services is linked to the economic security of society. This means that it is a class issue where richer areas have more natural elements than the poorer ones. Studies show that the use of green areas is much higher for the upper and middle classes in societies when priorities changes with an increased financial security (Elmqvist et al., 2015; Riechers et al., 2018; Wilkerson et al., 2018).

\section{Economic effects}

The prioritization of urban ecosystem services varies widely between countries. Developing countries usually prioritize economic growth, above all else, unlike western countries where the environment is an increasingly growing issue, but all countries have environmental problems to a greater or lesser extent. These problems are an increasingly growing financial expense for countries where investment in new technology and clean-up is needed to restore nature. These expenses are ultimately linked to human health and well-being, which in turn affects our society (Gustafsson et al., 2018; Wang Y. et al., 2018). Implementing urban ecosystem services is usually faced with economic growth as they use commercial land areas that can generate jobs for society. In addition, they require financial maintenance for management and do not give rise to any direct income, so it is difficult to argue the economic benefits (Elmqvist et al., 2015; Li et al., 2017; Bissonnette et al., 2018). But they give rise to indirect savings in society as the previous example of city parks where they reduce stress can provide an indirect saving for reduced sick leave and a reduced burden on health care. For countries with warmer climates, parks can give rise to microclimate that lowers the temperature with their vegetation and thus reduce energy consumption for climate systems (Nielsen-Pincus et al.. 2017; Vallecillo et al.. 2019).

\section{Valuation methods}

\section{PES - Paying-for-Ecosystem Services}

Paying for ecosystem services (PES) is a method for providing incentives for environmental management that is used primarily by governments and companies. The method aims to provide an additional cost to be used by the managers to maintain one or more ecosystem services that provides those who are considered as users or those who benefit from the service. The PES method can be developed around specific ecosystem services such as drinking water quality or around the more general environmental values such as the preservation of e.g. biodiversity (Rodríguez-Loinaz et al., 2018; Sirakaya et al., 2018; Wang Y. et al., 2018).

However, the PES method has been criticized for being often used solely by economic values and should instead focus on moral values that are based in the environment (Lima et al., 2017; Nielsen-Pincus et al., 2017).

\section{WTP / WTA - Willingness-To-Pay / Accept}

This method is a process for creating a basis for acceptance or financial evaluation for a change or implementation of a service. The basis is often from surveys where people or companies are asked what they are willing to pay or accept for a service or product. This method is common in the case of goods or services that do not have value on the market.

When it comes to goods and services that do not have a market value, demand is more significant, and when it comes to environmental goods it is usually a geographical issue of access (Adegun, 2017; Nielsen-Pincus et al., 2017; Xiao et al., 2017; Aguilar et al., 2018; Ariful Islam et al., 2018).

\section{Replacement cost}

The replacement cost method is used to allocate an economic value to an ecosystem service based on the cost of replacing such natural resource with a technical solution. The method can be applied if certain conditions are met: 1 ) the technology can provide the same nature service / $\mathrm{s}$ that are generated, 2) the chosen technology is the cheapest option for the examined nature service, and 3) there is a general demand for the chosen technology when the nature service is no longer available. One of the disadvantages of the replacement cost method is that technicians as alternatives to nature services only provide one or a limited set of services compared to the multifunctional ecosystems. In addition, it is difficult to find a perfect technological replacement for an ecosystem service (Meerow \& Newell, 2017; Silvennoinen et al., 2017; Groshans et al., 2018; Nikodinoska et al., 2018). 


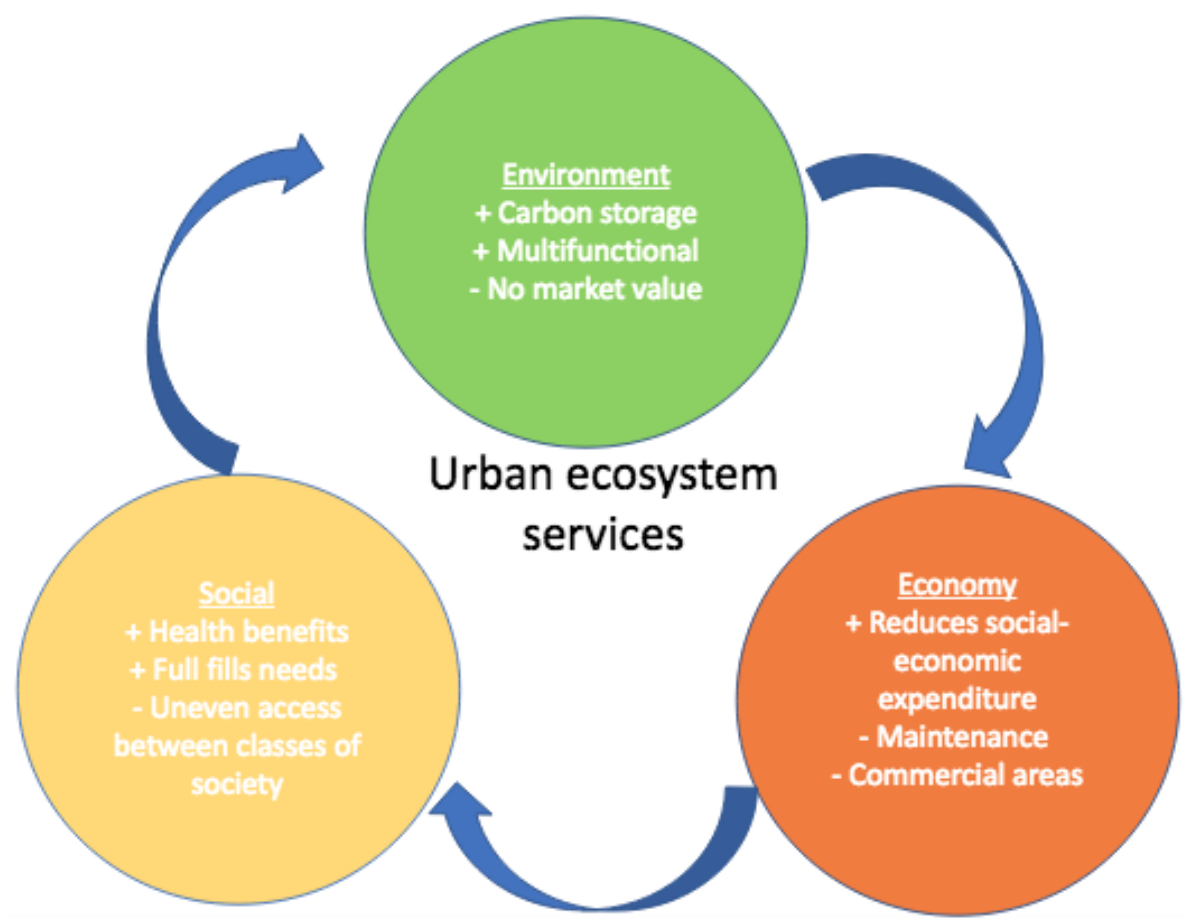

Figure 2. Flow picture for how urban ecosystem services can correlate with the three aspects: Economy, social and environment

\section{Discussion}

There are several interesting reflections that can be made from the literature review presented here in relation to the three aspects of the environment, economy and social. There were few articles that chose to look at the problems from all three aspects from a sustainability perspective.

From the literature it has been a problem to weigh the pros and cons against each other for these three aspects. So therefore it will be discussed about urban ecosystem services from these three aspects.

\section{Environmental aspect}

How we plan our societies is one of the keys to sustainable development. Implementing ecosystem services in urban planning, so-called green infrastructure, has many benefits that can help our well-being and strengthen our finances.

Therefore it is important to have knowledge of the multifunctional properties of ecosystem services. According to (Wang J. \& Banzhaf, 2018), it is important to know what features the services provide and how they work, both to adapt them to new urban environmental challenges and to mitigate urban environment problems, increase resilience and maintain quality of life. Multifunctionality should be regarded as a step in the decision-making process, where we make choices between functions in order to best adapt them to the needs of society in order to put them in correlation with economic gain.

Having a well-functioning green infrastructure can include the properties they give rise to, for example. biodiversity conservation and cooling effects from green roofs, recreational accessibility, heat control of urban gardens. Knowledge helps increase social recognition of how people benefit from our ecosystems that are part of the green infrastructure. If ecosystem services become part of our urban planning and prove the link between the environment and social processes, it can maintain or even improve people's well-being and thus promote sustainable urban development.

\section{Social aspect}

Implementing ecosystem services in society does not have the same importance or priority for different countries in the world. The issue of prioritization is often defined by which government prevails in the country and the economic situation. For developing countries, economic growth is often prioritized and then the environmental aspect and the social aspect are often ignored if there is great poverty in the country. But regardless ecosystem services are in some way a part of society, which often depends on the needs of the population.

In South Africa, there are large social gaps and is an example of what ecosystem services have for the different classes. (Wilkerson et al., 2018) study shows that the upper and middle classes tend to often use their plots for vegetation that increase the visual beauty to satisfy their needs. If you look at the subclass then the plots are usually used for fruit trees or other vegetation that yields a return to safeguard the need for food as they often have an economic uncertainty.

So the question of how ecosystem services are to be used in a society depends on the needs that the population wants to fulfil. It is therefore important to see in the urban planning what needs exist and thus adapt 
the ecosystem services for this but also to ensure a safe living environment. Looking at the development in China and India where large expansions of housing and companies occur and where one often ignores the construction of green areas even though it has been found that there is a large demand from the population according to (Wei et al., 2018; Zinia \& McShane, 2018). Many use green areas to unwind and feel a little closer to nature but also that trees have great advantages in large cities and especially in warmer countries where they help to ventilate and cool the air. Many studies indicate that we have a strong connection to nature and that they help to strengthen the well-being of the population.

So social factors can have a profound influence on the demand and supply of urban ecosystem services, and bring many benefits to the city's inhabitants from green spaces. Therefore, urban planning that includes these features can design and provide green spaces that can potentially improve health and wellbeing. (Wilkerson et al., 2018) believes that moving towards a sustainable society, urban planning must include the needs that the population demands and inform about its properties so that they are accepted and become part of society.

\section{Economic aspect}

Arguing for ecosystem services from an economic perspective is difficult as they often lack a commercial value on the market. Therefore, they must be valued to obtain a basis so that decisions that are made have an integrated economic value where the environment receives the same priority as the economic and social. Many cities have chosen to remove the ecosystems that exist in the immediate vicinity to make room for companies and industries to stimulate economic growth, which in some cases has led to great economic consequences.

Houston, Texas is an example of what happens if one ignores the importance of ecosystem services and it's functions. Houston is a well-developed industrial city that is located near a desert, which means that they have more extreme weather conditions. The whole city area has largely been covered with concrete and asphalt and has very few green areas. These conditions mean that in the event of more severe rainfall, which often occurs around the deserts, it causes great flooding in the city since the water must be led out of the city instead of running through it. Had the city e.g. used parks and forest areas integrated into the city, the water could go down through the city as trees help prevent erosion and that it helps to create groundwater that is in short supply in Houston, which has also been contaminated by the floods. Not having taken ecosystem services into account has cost the city large sums of money and many people's lives. Florida, too, has problems with floods that are of the rising sea levels but are linked to climate change. This has meant that they have to invest in large drainage and pumping systems to avoid the greatest devastation caused by floods according to (Berland et al., 2017; BenDor et al., 2018; Czajkowski et al., 2018).

The importance of ecosystem services is not only the direct effect but also the long-term, which helps to balance the various fluctuations of human emissions. Calculating the economic value of ecosystem services provides useful arguments for environmental improvements but is often insufficient to fully capture the scope of the benefits of restoring ecosystem services in cities. This is because the value is more dependent on time and its ability to balance environmental changes. But this can be perceived as inflated values to promote ecosystem services, which means that the basis for the valuation must be able to argue for itself (Elmqvist et al., 2015).

Investing in restoring, protecting and improving green infrastructure and ecosystem services in cities is not only good for the environment but also socially desirable. They are often economically feasible, for many western countries, provided that the multifunctional characteristics and all other benefits to the local population are counted. Such information is necessary to include in decision-making processes and use as a basis for setting an economic value for land use and management in society. It can help and guide city planners in the decision-making process as well as private and other stakeholders.

\section{Implementation methods}

The difficulty with ecosystem services is that these are usually a general resource that has no commercial value on the market. In addition, the valuation has a strong link to the size of the resource available in a given region.

In Sweden, there is a very large supply of fresh water and therefore has a lower value in the eyes of the population as opposed to a country such as Australia who has a shortage of it and must invest in expensive technology in order to meet the population's needs. Therefore, it is very difficult to be able to set fixed values for ecosystem services and its returns (Varis et al., 2017).

Paying-for-Ecosystem-Services or PES is a concept of the willingness to pay to build ecosystem services that contribute to improving the environment or other products that nature provides. PES has been applied in New York and Munich where it cleans the river basin, which is a source of fresh water for the population using ecosystem services (Aguilar et al., 2018; BenDor et al., 2018). The method is used as a premium on the bill or tax on drinking water that is earmarked to go to the improvement of the water quality. The method can be compared with WTP but differs as it must be valued on the basis of the population who are connected to the service and what they are willing to pay or accept to have it delivered. WTP is an interesting method as it helps to create an idea of how ecosystem services are valued by the population. But it requires that there is enough infor- 
mation available to be able to get the desired effect and that it focuses on different target groups. The richer part of the population usually uses resources in larger quantities and can pay for minor changes, unlike the middle and subclasses that are more sensitive to change.

The compensation method is more focused on companies and industries, as they often use natural areas to establish themselves. The method should be done in conjunction with an EIA (environmental impact assessment) as it can be very difficult to estimate the layout of the local area and how it is affected by the change. It's based on roughly the same principle as PPP (Polluter-Pays-Principle) where you pay for the changes you give rise to. But it gives rise to many issues such as cumulative effects, assets in the immediate area and valuations of services etc. In order for it to work better, I believe that one must look at the entire ecosystem and value it, then see percentage to how much land that is seized and then earmark the value when an implementation must take place to preserve the ecosystems.

\section{Conclusion}

From the literature study it feels that the recurring problem is how we look at urban ecosystem services and how little understanding we have of its functions in society. The reason was perceived as a lack of knowledge that makes it possible to put them in correlation with economic and social aspects. From the literature it feels that there is no basis for looking at ecosystem services from all three aspects mentioned above: Economics, social and environment.

To fill the gaps from the literature study, further studies should be carried out in these areas:

- How to increase knowledge about the multifunctional properties of ecosystem services and how they contribute to our society.

- Examine the connection between people's well-being and nature.

- Analysing ecosystem services within the three-base-line for sustainable development: Environment, social, economy

- Create a basis for how ecosystems should be valued in order to increase its prioritization in society.

\section{Acknowledgments}

Thanks to Venkatesh for providing good guidance and providing literature.

\section{References}

1. ADEGUN O., 2017, Developing Green Infrastructure in a Johannesburg Informal Settlement: Investigating Residents' Willingness to Pay, in: Procedia Engineering, 198, p. 176-186.
2. AGUILAR F. X OBENG E. A., CAI Z, 2018 , Water quality improvements elicit consistent willingness-to-pay for the enhancement of forested watershed ecosystem services, in: Ecosystem Services, 30, p. 158-171.

3. AMANO T., BUTT I. PEH K. S.-H., 2018, The importance of green spaces to public health: a multi-continental analysis, in: Ecological Applications, 28(6), p. 1473-1480.

4. ANDERSSON-SKÖLD Y., KLINGBERG J., GUNNARSSON B., CULLINANE K., GUSTAFSSON I., HEDBLOM M., KNEZ I., LINDBERG F., ODE S. Å., PLEIJEL, H., THORSSON P., THORSSON S., 2018, A framework for assessing urban greenery's effects and valuing its ecosystem services, in: Journal of Environmental Management, 205, p. 274-285.

5. ARITFUL ISLAM M., AHMAD S.A., ISLAM R., 2018, Estimating Willingness to Pay for Improving River Water Quality Using Contingent Valuation Method: A Conceptual Framework, in: International Journal of Management, Accounting \& Economics, 5(8), p. 643-657.

6. BENDPR T. K., SHANDAS V., MILES B., BELT K., OLANDER L., 2018, Ecosystem services and U.S. stormwater planning: An approach for improving urban stormwater decisions, in: Environmental Science and Policy, 88, p. 92-103.

7. BERLAND A., SHIFLETT S. A., SHUSTER W. D., GARMESTANI A. S., GODDARD H. C., HERRMANN D. L., HOPTON M. E., 2017, The role of trees in urban stormwater management, in: Landscape and Urban Planning, 162, p. 167-177.

8. BISSONNETTE J.-F., DUPRAS J., MESSIER C., LECHOWICZ M., DAGENAIS D., PAQUETTE A., JAEGER J. A. G., GONZALES A., 2018, Moving forward in implementing green infrastructures: Stakeholder perceptions of opportunities and obstacles in a major North American metropolitan area, in: Cities, 81, p. 61-70.

9. CHEN X., de VRIES S., ASSMUTH T., DICK J., HERMANS T., HERTEL O., JENSEN A., JONES L., KABISCH S., LANKI T., LEHMANN I., MASKELL L., NORTON L., REIS S., 2018, Research challenges for cultural ecosystem services and public health in (peri-)urban environments, in: Science of The Total Environment, 651, p. 2118-2129.

10. CHIABAI A., QUIROGA S., MARTINEZJUAREZ P., HIGGINS S., TAYLOR T., 2018, The nexus between climate change, ecosystem services and human health: Towards a conceptual framework, in: Science of The Total Environment, 635, p. 1191-1204.

11. CHIARA C., 2018, Ecosystem services in urban plans: What is there, and what is still needed for better decisions - ScienceDirect.

12. CZAJKOWSKI J., ENGEL V., MARTINEZ C., MIRCHI A., WATKINS D., SUKOP M. C., HUGHES J. D., 2018, Economic impacts of urban flooding in South Florida: Potential consequences of managing groundwater to prevent salt water intrusion, in: Science of The Total Environment, 621, p. 465-478. 
13. DEMUZERE M., ORRU K., HEIDRICH O., OLAZABAL E., GENELETTI D., ORRU H., BHAVE A. G., MITTAL N., FELIU E., FAEHNLE M., 2014, Mitigating and adapting to climate change: Multi-functional and multiscale assessment of green urban infrastructure, in: Journal of Environmental Management, 146. P. 107-115.

14. DERKZEN M. L., van TEEFFELEN A. J. A., VERBUNG P. H., 2017, Green infrastructure for urban climate adaptation: How do residents' views on climate impacts and green infrastructure shape adaptation preferences?, in: Landscape and Urban Planning, 157, p. 106-130.

15. ELMQVIST T., SETÄLÄ H., HANDEL S., van der PLOEG S., ARONSON J., BLIGNAUT J., GÓMEZ-BAGGETHUN E., NOWAK D., KRONENBERG J., de GROOT R., 2015, Benefits of restoring ecosystem services in urban areas, in: Current Opinion in Environmental Sustainability, 14, p. 101-108.

16. FELTYNOWSKI M., KRONENBERG J., BERGIER T., KABISCH N., ŁASZKIEWICZ E., STROHBACH M. W., 2018, Challenges of urban green space management in the face of using inadequate data, in: Urban Forestry \& Urban Greening, 31, p. 56-66.

17. GROSHANS G. R., MIKHAILOVA E. A., POST C. J., SCHLAUTMAN M. A., ZURQANI H. A., ZHANG L., 2018, Assessing the Value of Soil Inorganic Carbon for Ecosystem Services in the Contiguous United States Based on Liming Replacement Costs, in: Land, 7(4), p. 149.

18. GUSTAFSSON S., HERMELIN B., SMAS L., 2018, Integrating environmental sustainability into strategic spatial planning: the importance of management, in: Journal of Environmental Planning and Management.

19. HEGETSCHWEILER K. T., de VRIES S., ARNBERGER A., BELL S., BRENNAN M., SITER N., OLAFSSON A. S., VOIGHT, A., HUNZIKER M., 2017, Linking demand and supply factors in identifying cultural ecosystem services of urban green infrastructures: A review of European studies, in: Urban Forestry \& Urban Greening, 21, p. 48-59.

20. HUANG L., CAO W., XU X., FAN J., WANG J., 2018, Research article: Linking the benefits of ecosystem services to sustainable spatial planning of ecological conservation strategies, in: Journal of Environmental Management, 222, p. 385-395.

21. JIANG W., 2017, Ecosystem services research in China: A critical review, in: Ecosystem Services, 26, p. 10-16.

22. KIM D., JIN J., 2018, Does happiness data say urban parks are worth it?, in: Landscape and Urban Planning, 178, p. 1-11.

23. LI F., LIU X., ZHANG X., ZHAO D., LIU H., ZHOU C. , WANG R., 2017, Urban ecological infrastructure: an integrated network for ecosystem services and sustainable urban systems, in: Journal of Cleaner Production, 163, p. S12-S18. 24. LIMA L. S. de KRUEGER T., GARCIA-MARQUEZ, J., 2017, Uncertainties in demonstrating environmental benefits of payments for ecosystem services, in: Ecosystem Services, 27, p. 139149.

25. MABON L., SHIH W.-Y., 2018, What might 'just green enough' urban development mean in the context of climate change adaptation? The case of urban greenspace planning in Taipei Metropolis, Taiwan, in: World Development, 107, p. 224-238.

26. di MARINO M., LAPINTIE K., 2018, Exploring the concept of green infrastructure in urban landscape. Experiences from Italy, Canada and Finland, in: Landscape Research, 43(1), p. 139149.

27. MEEROW S., NEWELL J. P., 2017, Spatial planning for multifunctional green infrastructure: Growing resilience in Detroit, in: Landscape and Urban Planning, 159, p. 62-75.

28. MEXIA T., VIEIRA J., PRÍNCIPE A., ANJOS A., SILVA P., LOPES N., FREITAS C., SANTOS-REIS M., CORREIA O., BRANQUINHO C., PINHO P., 2018, Ecosystem services: Urban parks under a magnifying glass, in: Environmental Research, 160, p. 469-478.

29. NATURVÅRDSVERKET, 2015, Guide för värdering av ekosystemtjänster, Naturvårdsverket, Stockholm.

30. NATURVÅRDSVERKET, 2019, Vad är ekosystemtjänster?,https://www.naturvardsverket.se/Miljoarbete-i-samhallet/Miljoarbete-iSverige/Uppdelat-efter-omrade/Ekosystemtjanster/Vad-ar-ekosystemtjanster/ (16.01.2019).

31. NIELSEN-PINCUS M., SUSSMAN P., BENNETT D. E., GOSNELL, H., PARKER R., 2017, The Influence of Place on the Willingness to Pay for Ecosystem Services, in: Society \& Natural Resources, 30(12), p. 1423-1441.

32. NIKODINOSKA N., PALETTO A., PASTORELLA F., GRANVIK M., FRANZESE P. P., 2018, Assessing, valuing and mapping ecosystem services at city level: The case of Uppsala (Sweden), in: Ecological Modelling, 368, p. 411-424.

33. REGERINGSKANSLIET R., 2015, Ekosystem och biologisk mångfald, https://www.regerin gen.se/regeringens-politik/globala-malen-ochagenda-2030/ekosystem-och-biologisk-mangfald/ (16.01.2019).

34. RIECHERS M., BARKMANN J., TSCHARNTKE T., 2018, Diverging perceptions by social groups on cultural ecosystem services provided by urban green, in: Landscape and Urban Planning, 175, p. 161-168.

35. RODRÍGUEZ-LOINAZ G., PEÑA L., PALACIOS-AGUNDEZ I., AMETZAGA I., ONAINDIA M., 2018, Identifying Green Infrastructure as a Basis for an Incentive Mechanism at the Municipality Level in Biscay (Basque Country), in: Forests, 9(1), p. 22.

36. ROEBELING P., SARAIVA M., PALLA A., GNECCO I., TEOTÓNIO C., FIDELIS T., MARTINS F., ALVES H., ROCHA J., 2017, Assessing the socio-economic impacts of green/blue space, urban residential and road infrastructure projects in the Confluence (Lyon): a 
hedonic pricing simulation approach, in: Journal of Environmental Planning and Management, 60(3), p. 482-499.

37. SHACKLETON R. T., ANGELSTAM P., van der WAAL B., ELBAKIDZE M., 2017, Progress made in managing and valuing ecosystem services: a horizon scan of gaps in research, management and governance, in: Ecosystem Services, 27, p. 232-241.

38. SILVENNOINEN S., TAKA M., YLI-PELKONEN V., KOIVUSALO H., OLLIKAINEN M., SETÄLÄ H., 2017, Monetary value of urban green space as an ecosystem service provider: A case study of urban runoff management in Finland, in: Ecosystem Services, 28, p. 17-27.

39. SIRAKAYA A., CLIQUET A., HARRIS J., 2018, Ecosystem services in cities: Towards the international legal protection of ecosystem services in urban environments, in: Ecosystem Services, 29, p. 205-212.

40. VALLECILLO S., LA NOTTE A., ZULIAN G., FERRINI S., MAES J., 2019, Ecosystem services accounts: Valuing the actual flow of nature-based recreation from ecosystems to people, in: Ecological Modelling, 392, p. 196-211.

41. VALLECILLO S., POLCE C., BARBOSA A., PERPIÑA CASTILLO C., VANDECASTEELE I., RUSCH G. M., MAES J., 2018, Spatial alternatives for Green Infrastructure planning across the EU: An ecosystem service perspective, in: Landscape and Urban Planning, 174, p. 41-54.

42. VARIS O., KESKINEN M., KUMMU M., 2017, Four dimensions of water security with a case of the indirect role of water in global food security, in: Water Security, 1, p. 36-45.
43. WANG J., BANZHAF E., 2018, Towards a better understanding of Green Infrastructure: A critical review, in: Ecological Indicators, 85, p. 758-772.

44. WANG Y., LI X., SUN M., YU H., 2018, Managing urban ecological land as properties: Conceptual model, public perceptions, and willingness to pay, in: Resources, Conservation and Recycling, 133, p. 21-29.

45. WANG Y.-C., SHEN J.-K., XIANG W.-N., 2018, Ecosystem service of green infrastructure for adaptation to urban growth: function and configuration, in: Ecosystem Health and Sustainability, 4(5), p. 132-143.

46. Wei, J., Qian, J., Tao, Y., Hu, F. \& Ou, W. (2018). Evaluating Spatial Priority of Urban Green Infrastructure for Urban Sustainability in Areas of Rapid Urbanization: A Case Study of Pukou in China, in: Sustainability, 10(2), 327.

47. WILKERSON M. L., MITCHELL M. G. E., SHANAHAN D., WILSON K. A., IVES C. D., LOVELOCK C. E., RHODES J. R., 2018, The role of socio-economic factors in planning and managing urban ecosystem services, in: Ecosystem Services, 31(Part A), p. 102-110.

48. XIAO Y., LU Y., GUO Y., YUAN Y., 2017, Estimating the willingness to pay for green space services in Shanghai: Implications for social equity in urban China, in: Urban Forestry \& Urban Greening, 26, p. 95-103.

49. ZINIA N. J., MCSHANE P., 2018, Ecosystem services management: An evaluation of green adaptations for urban development in Dhaka, Bangladesh, in: Landscape and Urban Planning, 173, p. 23-32. 
